\title{
Mandibular Condyle Repair after Partial Condylectomy in Patients with Active Condylar Hyperplasia
}

\author{
Reparación de Cóndilos Mandibulares Después de \\ Condilectomía Parcial por Hiperplasia Condilar Activa \\ Sergio Olate ${ }^{*, * *}$; Mario Cantín ${ }^{* * *, * * * *}$; Celso Palmieri ${ }^{* * * * *}$; \\ Juan Pablo Alister ${ }^{*, * * * * * * *}$; Mariela Muñoz ${ }^{* * * * * * * *}$ \& Márcio de Moraes ${ }^{* *}$
}

OLATE, S.; CANTÍN, M.; PALMIERI, C.; AlISTER, J. P.; MUÑOZ, M. \& DE MORAES, M. Mandibular condyle repair after condylectomy in patients with condylar hyperplasia. Case series report. Int. J. Morphol., 33(2):759-763, 2015.

SUMMARY: The different aspects of unilateral condylar hyperplasia have been studied and continue to be controversial; nevertheless, treatment based on condylectomy has been established as part of the working protocol. The aim of this investigation was to identify the bone repair observed in surgically treated condyles after 1 year using cone beam computed tomography (CBCT). Nine subjects were included in this study ( 6 female and 3 male) with an average age of 18.5 years. They had been diagnosed with active unilateral condylar hyperplasia using SPECT, clinical follow-up of progressive facial asymmetry and CBCT. Patients underwent exclusive condylectomy surgery with a piezoelectric system without disc replacement, orthognatic surgery or any other type of adjunct surgical procedure. Later, they were treated orthodontically for dental compensation or as preparation for orthognatic surgery. A CBCT was performed in the first postoperative month and after 1 year from the surgery to analyze variables. The CBCT at 1 month showed a clear and distinct slice of the condyle without defects or irregularities; the distance from the condylar remnant to the articular fossa reached $8.5 \mathrm{~mm}$ in the most extreme case. After 1 year, condylar bone remodeling was observed, with areas of lateral and superior curvature and characteristics of normal condyles, with cortical bone present and a maximum distance of $4.5 \mathrm{~mm}$ from the condylar fossa. In conclusion, condylar repair and remodeling can be obtained in these types of surgeries and the morphology of resected condyles after 1 year is quite close to normal macroscopic anatomy.

KEY WORDS: Condylectomy; Bone remodeling; Condylar hyperplasia.

\section{INTRODUCTION}

Hyperplasia is defined as the growth in the number of cells present in a certain tissue with no increase in their size. When this affects one of the mandibular condyles, it is called unilateral condylar hyperplasia (UCH) and is characterized as presenting alterations to both the condylar and facial morphology (Olate et al., 2013a).

The diagnosis of active $\mathrm{UCH}$ is somewhat controversial in terms of recognizing the best diagnostic methods (Olate et al., 2013b). Nowadays, the combination of different parameters of nuclear medicine, clinical studies and imaging follow-up could determine the progressive and active nature of UCH.
However, the treatment for $\mathrm{UCH}$ does have some consensus: Olate et al. (2013b) conducted a study indicating that of 12 articles published, 10 presented the high condylectomy of the mandibular condyle as the treatment of choice with or without use of complementary techniques such as orthognatic surgery and joint disc replacement, among others. Recently, the study by Fariña et al. (2015) modified the osteotomy levels while keeping the partial resection of the condylar head as an adequate treatment. It has also been reported that postoperative joint function after a condylectomy does not present any complications, with stable functioning and an absence of pain (Olate et al., 2014a), demonstrating

* Division of Oral and Maxillofacial Surgery, Universidad de La Frontera, Temuco, Chile.

** Division of Oral and Maxillofacial Surgery, State University of Campinas, Campinas, Brazil.

*** Center for Biomedical Research, Universidad Autónoma de Chile, Temuco, Chile.

**** PhD Program in Morphology, Universidad de La Frontera, Temuco, Chile.

****** Department of Oral and Maxillofacial Surgery, Louisiana State University Health Shreveport, Shreveport, United States.

******* PhD Program in Medical Sciences, Universidad de La Frontera, Temuco, Chile.

${ }^{* * * * * * * *}$ Fellow Researcher, Universidad Científica del Sur, Lima, Perú. 
the efficiency of the technique. However, postoperative condylar morphology and reparation has not been analyzed.

The aim of this study was to define the repair and morphology observed in mandibular condyles of temporomandibular joint (TMJ) with UCH diagnosis, treated with a condylectomy.

\section{MATERIAL AND METHOD}

Diagnosis and surgical procedure. Nine individuals were included in this report aged from 15 to 20 years (6 female and 3 male), who underwent a high or proportional condylectomy for a diagnosis of UCH. The methodology of diagnosis and treatment of the subjects has been reported previously and followed the sequence described by Olate $e t$ al. (2013b), using clinical studies of facial and dental analysis, computed cone beam tomography (CBCT) for the condylar analysis and analysis with single photon emission computed tomography (SPECT), diagnosing the progressive facial asymmetry associated with active UCH. Clinically, the patients presented a chin deviation greater than $5 \mathrm{~mm}$ toward the contralateral side, with a posterior cross-bite and free of joint pain symptoms. In all the subjects, the gonion of the hyperplastic side was lower and more medially positioned than the contralateral gonion.

The surgery consisted of the partial resection of the condylar head using a high or proportional condylectomy. The surgery was performed under general anesthesia, using a preauricular or endaural access until arriving at the osteotomy, which was conducted with an ultrasound system (Piezotome2®, Satelec Action). The disc was not repositioned with sutures or by mobilization techniques, maintaining its integrity during the surgery. All the patients underwent subsequent orthodontic treatment, where some were enrolled for treatment with orthognatic surgery while others were treated exclusively with corrective orthodontics.

Analysis and follow-up with 3D imaging. For all the subjects, CBCT (PlanMeca®, Korea) was used for all the initial examinations. After the surgery, the first analysis was done with imaging within the first month and between 12 and 16 months after the procedure.

All the images were obtained using the same equipment, which was operated by two previously trained technicians. The images were analyzed with the EZ3D plus software (2009) by a single observer on three different occasions 15 days from the initial measurement in order to reduce analytical error.
The variables observed were condylar morphology, presence of cortical bone and spatial relation with articular fossa, employing a descriptive and qualitative analysis for their study.

\section{RESULTS}

The surgeries and evaluations with 3D imaging occurred without complications.

Preoperative condition: In every case an increase was observed in the size of the condyle in all the relations observed, on the axial, coronal and sagittal planes. The hyperplastic condyles were shown to have cancellous bone and peripheral cortical bone; there was cortical bone discontinuity in some cases (Fig. 1).

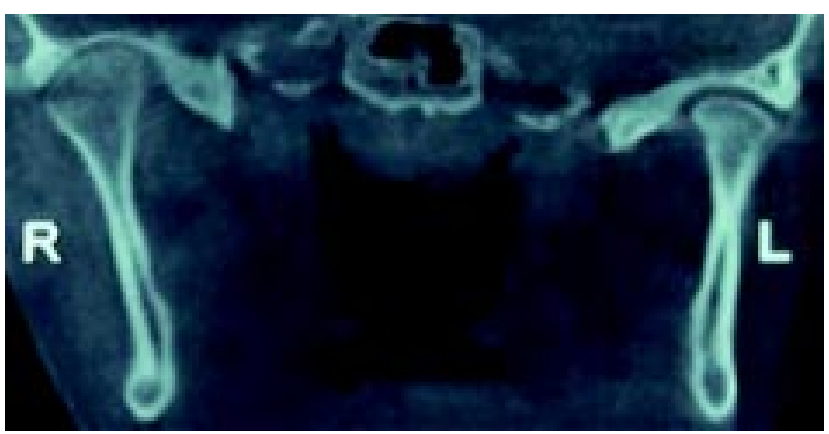

Fig. 1. CBCT image of hyperplastic condyle prior to surgery.

Initial postoperative condition: All the condyles treated with the procedure were clearly seen in the slice, which was taken horizontally, reaching all the areas of the affected condyle. The treated condyles appeared 3.5 to 8.5 $\mathrm{mm}$ (average $5.3 \mathrm{~mm}$ ) distant from the articular fossa because the mandibular rotation in most patients involved premature contact in the area of the contralateral molars, preventing the correctly approach to the articular fossa (Fig. 2).

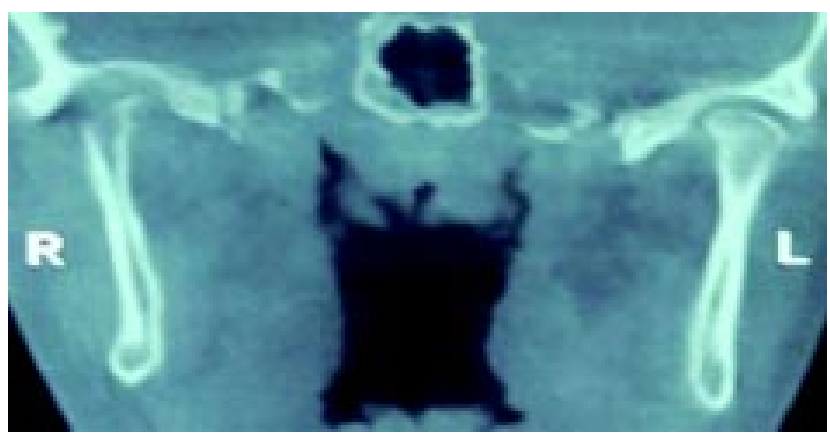

Fig. 2. CBCT image of treated condyle 3 weeks after condylectomy; clear osteotomy and without defects. 
Late postoperative condition: Greater approach to the articular fossa was observed; the larger joint space reached $4.5 \mathrm{~mm}$, with most presenting a joint space close to 2.5 to $3.0 \mathrm{~mm}$ (average $3.7 \mathrm{~mm}$ ). Bone repair was observed in all the condyles assessed, including partial corticalization in all of them. Condylar morphology revealed the presence of a curved area similar to the morphology of a normal condyle, although with the smaller head (Fig. 3).

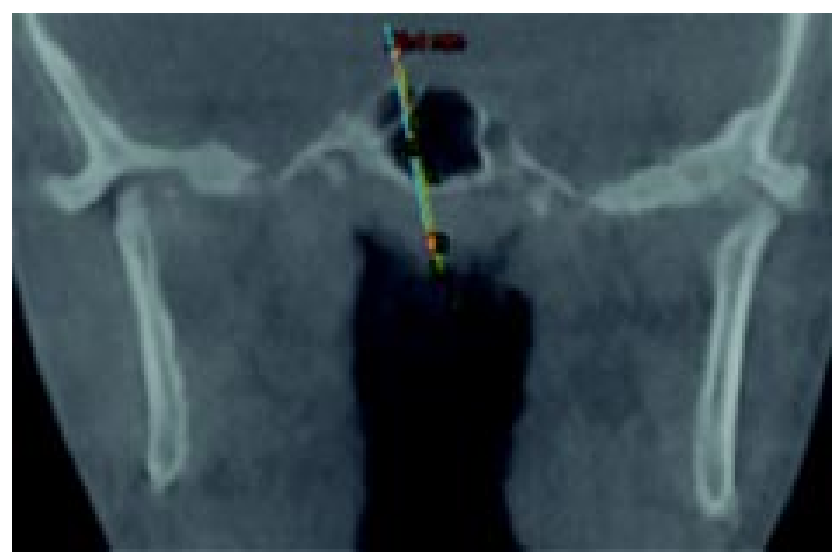

Fig. 3. CBCT image of treated condyle 13 months after the procedure; clear areas of condylar regeneration are observed with sectors of cortical bone formation.

\section{DISCUSSION}

$\mathrm{UCH}$ has been widely analyzed in recent years without obtaining any clear consensus in terms of etiology and diagnosis (Olate et al., 2013b; Wolford et al., 2014). The studies conducted to determine its physiopathology have not been conclusive, indicating some histological aspects of the disease without managing to identify the processes involved in its development or sequence (Saridin et al., 2010). It has been established that fibrocartilage growth is part of the development of the disease (Saridin et al.; Eslami et al., 2003), whereas histopathological classifications of normality and disease have not been clear in terms of criteria.

The morphological characteristics of the $\mathrm{UCH}$ have been reported clinically with the classic facial asymmetry, chin deviation and unilateral cross-bite (Olate et al., 2013a), which being progressive help to determine the activity of the disease. The macrocospic morphology of the condyle has recently been analyzed by two studies published by the group at the Universidad de La Frontera (Olate et al., 2013c; Muñoz et al., 2014), describing the form of the hyperplastic condyle and its relations with contralateral condyles and mandibular morphology; these studies determined a clear volume increase in the hyperplastic condyle (more elongated as well as a transverse increase) and the difference observed in the non-hyperplastic condyle and its relation to the facial asymmetry.

Using computed microtomography it was recently observed that the hyperplastic condyle has an increase in cancellous bone, disorganized, with perforations in the condylar head (Karssemakers et al., 2014). Our results showed that in the preoperative images, both segmented and volumetric, there were defined areas of cortical bone and cancellous bone. In some upper cortical areas of the condylar head a loss of cortical continuity was observed, which may suggest areas of bone remodeling.

After the surgery, performed completely with a piezoelectric system (Piezotome2®, Satelec Action) according to the technique proposed by Olate et al., 2014b, a clear and distinct slice was observed with no areas of bone defects or alterations in the slice, exhibiting a distance of up to $8 \mathrm{~mm}$ from the articular fossa to the treated condyle. This is due mainly to there being a mandibular rotation posterior and superior to the surgically treated side after the condylar osteotomy, with the fulcrum of movement being the nonhyperplastic condyle. Often premature contacts of the contralateral side at molar level are produced, preventing full elevation of the treated condyle. One year after the surgery, imaging revealed a clear sign of regeneration likely due to bone apposition with cortical structure, which was partial in every case. This hypothesis of growth is supported by the fact that the premature contacts observed in the initial postoperative phase cannot be solved before early with orthodontic forces (compensatory orthodontics and use of elastics or preparatory orthodontics for orthognatic surgery), which limits the elevation and positioning of the treated condyle. This would imply that the condyle must be adapted and remodeled with bone apposition and the resulting growth of the condylar head (Villanueva-Alcojol et al., 2011).

This hypothesis may also be associated with the capacity of the hyperplastic mandibular condyle (with more cancellous bone) combined with fluids from the remaining joint capsule and the same contact with the disc soft tissues to influence the adaptation and repair of condylar bone tissues. The postoperative condylar morphology after 1 year from the surgery is clearly close to the morphology of normal condyles, having a rounded structure and a clear presence of cortical bone. The surgical technique, performed with a piezoelectric system, can also influence this recovery as it has been observed that the vibration of the system might stimulate the expression of factors associated with bone repair (Olate etal., 2013d)

To the knowledge of these authors, there is nothing in the anatomy, pathology or surgery literature regarding the 
use of magnetic resonance to study these conditions or reports of follow-up with CBCT, so it is difficult to compare our results. The condylar growth patterns in these types of procedures could contribute to a better understanding of regenerative processes since if a similar macromorphology is obtained between a treated condyle and a normal condyle, it is possible that a similar micromorphology is also obtained, including the presence of layers known to be in the normal condylar head. The resected condyle, initially with low vascularization, could lead to a secondary repair, considering that the development of hypertrophic cartilage in its final stage determines bone growth by endochondral methods with low mechanical resistance (Chen et al., 2015). In fact, during skeletogenesis in the embryological stage, the initial formation of basic cartilage is avascular at first; when the chondrocytes finalize their hypertrophic process, they are invaded by blood vessels (Maes, 2013), a condition that can be hypothesized in this case series. Ethical considerations prevent histological studies from being obtained from ani- mal experiments that could be useful for these analyses.

The load force, articular disc and the age of patients are important factors in the condylar repair. Miyamoto et al. (2002) observed that unilateral condylectomy showed better repair than bilateral condylectomy and related the force load in one side as the most important reason. In other research of Miyamoto et al. (2004), was realized unilateral condylectomy in the dog and after 3 months exist repair of the condylar head. On the other hand, Dimitroulis \& Slavin (2006) demonstrated (rabbits were operated with unilateral condylectomy) that hyaline cartilage was present in the condylar head with a total repair of the bone.

According to this research, it can be concluded that repair and adaptation exist in partially resected mandibular condyles when UCH is present; new information is needed to understand the physiopathological process present in this regenerative stage of the condyle.

OLATE, S.; CANTÍN, M.; PALMIERI, C.; ALISTER, J. P.; MUÑOZ, M. \& DE MORAES, M. Reparación de cóndilos mandibulares después de condilectomía parcial por hiperplasia condilar activa. Int. J. Morphol., 33(2):759-763, 2015.

RESUMEN: La hiperplasia condilar unilateral ha sido estudiada en diferentes aspectos y continua siendo controversial; aun así, el tratamiento en base a condilectomía se establece como parte del protocolo de trabajo. El objetivo de esta investigación es reconocer la reparación ósea observada en cóndilos operados después de 1 año mediante tomografía computadorizada cone beam (TCCB). Nueve sujetos fueron incluidos en este estudio (6 sexo femenino y 3 sexo masculino) con una edad promedio de 18,5 años; en ellos se realizó el diagnóstico de hiperplasia condilar unilateral activa mediante estudio de SPECT, seguimiento clínico de la asimetría facial progresiva y TCCB. Se realizó la cirugía de condilectomía exclusiva con sistema piezoeléctrico sin reposición de disco, cirugía ortognática u otro tipo de procedimiento quirúrgico adjunto; posteriormente, los pacientes fueron tratados ortodoncicamente para compensación dentaria o para preparación previa a cirugía ortognática. Se realizó TCCB dentro del primer mes postquirúrgico y después de 1 año de realizada la cirugía para análisis de variables. Se observó en la TCCB de 1 mes un corte nítido y neto del cóndilo, sin defectos o irregularidades; la distancia desde el remanente condilar hasta la fosa articular llegó hasta $8,5 \mathrm{~mm}$ en el caso máximo. Después de 1 año, se observo remodelación ósea condilar, con áreas de curvatura lateral y superior características de cóndilos normales, con presencia de hueso cortical y con una distancia máxima de $4,5 \mathrm{~mm}$ desde la fosa condilar. Se puede concluir que la reparación y remodelación condilar es viable de obtenerse en este tipo de cirugías y que la morfología de cóndilos resecados después de 1 año es bastante próxima de la anatomía macroscópica normal.

\section{PALABRAS CLAVE: Condilectomía; Remodelación ósea; Hiperplasia condilar.}

\section{REFERENCES}

Chen, S.; Fu, P.; Cong, R.; Wu, H. \& Pei, M. Strategies to minimize hypertrophy in cartilage engineering and regeneration. Genes Dis., 2(1):76-95, 2015.

Dimitroulis, G. \& Slavin, J. The effects of unilateral discectomy and condylectomy on the contralateral intact rabbit craniomandibular joint. J. Oral Maxillofac. Surg., 64(8):12616, 2006

Eslami, B.; Behnia, H.; Javadi, H.; Khiabani, K. S. \& Saffar, A. S. Histopathologic comparison of normal and hyperplastic condyles. Oral Surg. Oral Med. Oral Pathol. Oral Radiol. Endod., 96(6):711-7, 2003.
Karssemakers, L. H.; Nolte, J. W.; Tuinzing, D. B.; Langenbach, G. E.; Raijmakers, P. G. \& Becking, A. G. Microcomputed tomographic analysis of human condyles in unilateral condylar hyperplasia: increased cortical porosity and trabecular bone volume fraction with reduced mineralisation. $\mathrm{Br}$. J. Oral Maxillofac. Surg., 52(10):940-4, 2014

Fariña, R.; Pintor, F.; Pérez, J.; Pantoja, R. \& Berner, D. Low condylectomy as the sole treatment for active condylar hyperplasia: facial, occlusal and skeletal changes. An observational study. Int. J. Oral Maxillofac. Surg., 44(2):21725, 2015. 
Maes, C. Role and regulation of vascularization processes in endochondral bones. Calcif. Tissue Int., 92(4):307-23, 2013.

Miyamoto, H.; Matsuura, H.; Singh, J. \& Goss, A. N. Regeneration of the mandibular condyle after unilateral condylectomy and myotomy of the masseter in lambs. Br. J. Oral Maxillofac. Surg., 40(2):116-21, 2002.

Miyamoto, H.; Shigematsu, H.; Suzuki, S. \& Sakashita, H. Regeneration of mandibular condyle following unilateral condylectomy in canines. J. Craniomaxillofac. Surg., 32(5):296-302, 2004

Muñoz, P.; Goulart, D. R.; Olate, S.; de Moraes, M.; Navarro, P. \& Fariña, R. Analysis of the condyle, articular fossa and mandibular ramus in subjects with active condylar hyperplasia. Int. J. Morphol., 32(3):1064-8, 2014.

Olate, S.; Almeida, A.; Alister, J. P.; Navarro, P.; Netto, H. D. \& de Moraes, M. Facial asymmetry and condylar hyperplasia: considerations for diagnosis in 27 consecutives patients. Int J. Clin. Exp. Med., 6(19):937-41, 2013 a.

Olate, S.; Netto, H. D.; Rodriguez-Chessa, J.; ALister, J. P.; de Albergaria-Barbosa, J. \& de Moraes, M. Mandible condylar hyperplasia: a review of diagnosis and treatment protocol. Int. J. Clin. Exp. Med., 6(9):727-37, 2013 b.

Olate, S.; Cantín, M.; Alister, J. P.; Uribe, F.; Navarro, P.; Olate, G. $\&$ de Moraes, M. Relationship between condylar size and transverse facial asymmetry in subject with condylar hyperplasia. Int. J. Morphol., 31(3):937-41, $2013 \mathrm{c}$.

Olate, S.; Almeida, A.; Unibazo, A.; Alister, J. P.; Uribe, F.; Martínez, F. \& Huentequeo-Molina, C. Osteotomías craneomaxilofaciales con sistemas ultrasónicos. Rev. Chil. Cir., 65(5):454-62, $2013 \mathrm{~d}$.

Olate, S.; Unibazo, A.; Almeida, A. \& de Moraes, M. Mandibular condylectomy revisited: technical notes concerning the use of an ultrasonic system. J. Oral Maxillofac. Surg., 72(3):481-4, 2014a.

Olate, S.; Martinez, F.; Uribe, F.; Pozzer, L.; Cavalieri-Pereira, L. $\&$ de Moraes, M. TMJ function after partial condylectomy in active mandibular condylar hyperplasia. Int. J. Clin. Exp. Med., 7(3):775-9, 2014b.

Saridin, C. P.; Raijmakers, P. G., Slootweg, P. J.; Tuinzing, D. B.; Becking, A. G. \& van der Waal, I. Unilateral condylar hyperactivity: a histopathologic analysis of 47 patients. J. Oral Maxillofac. Surg., 68(1):47-53, 2010.

Villanueva-Alcojol, L.; Monje, F. \& González-García, R. Hyperplasia of the mandibular condyle: clinical, histopathologic, and treatment considerations in a series of 36 patients. J. Oral Maxillofac. Surg., 69(2):447-55, 2011.
Wolford, L. M.; Movahed, R. \& Perez, D. E. A classification system for conditions causing condylar hyperplasia. J. Oral Maxillofac. Surg., 72(3):567-95, 2014.

Correspondence to:

Prof. Dr. Sergio Olate

División de Cirugía Oral y Maxilofacial

Universidad de La Frontera

Claro Solar 115, Oficina 414-A

Temuco

CHILE

Email: sergio.olate@ufrontera.cl

Recibido : 09-01-2015

Aceptado: 22-04-2015 